\title{
MARINE UPPERMOST CRETACEOUS AND GARUMNIAN FACIES IN THE REGION OF BOIXOLS-COLL DE NARGO ANTICLINE (PROV. LERIDA. SPAIN)
}

\author{
H. Willems $\left({ }^{*}\right)$
}

\begin{abstract}
The lithostratigraphic evolution of marine uppermost Campanian-Maestrichtian (Arén Sandstone Formation) and of lagoonal and continental Maestrichtian-Paleocene "Garumrian" facies (Tremp Formation) on the southern margin of Boixols-Coll de Nargó Anticline was studied. Dating, based mainly on orbitoidal foraminifera, indicates that the formations are diachronous and become younger from west to east.

The transgression of the formations from south, respectively southwest upon Campanian to Santonian units, their tapering out northward, and the change in the pebble spectra (from Santonian to Aptian) of the conglomeratic layers reflect the elevation and denudation of the anticline uplift area ("island") at the Cretaceous-Tertiary boundary.

KEY WORDS: Paleogeography, paleoecology, synsedimentary tectonic, biostratigraphy, foraminifera, Upper Cretaceous-Lower Tertiary (Campanian-Maestrichtian-«Garumnian»), Spain, Pyrenees.
\end{abstract}

\section{RESUMEN}

Se estudia la evolución litoestratigráfica del Campaniense superior-Maastrichtiense marino (Formación Arenisca de Arén) y de las facies garumnienses continentales y de lagoon del Mastrichtiense (Formación Tremp) del borde sur del anticlinal de Boixols-Coll de Nargó. Las dotaciones, basadas principalmente en foraminíferos (Orbitoididae) indican que las formaciones son diacrónicas, disminuyendo en edad de oeste a este.

La transgresión de estas formaciones desde el sur y suroeste, respectivamente, sobre las unidades del Campaniense-Santoniense, su buzamiento norte, y el cambio del tamaño de los cantos (Santonienses-Aptienses) de las capas conglomeráticas, indican una elevación y erosión del área anticlinal emergida (isla) en el límite Cretácico-Terciario.

Palabras clave: Paleogeografía, paleoecología, tectónica sinsedimentaria, bioestratigrafia, foraminíferos, Cretácico superior-Terciario inferior (Campaniense-Maastrichtiense-«Garum. niense»), España, Pirineos.

\section{Introduction}

The area investigated lies in the South-Central Pyrenees in the Province of Lérida, Spain (fig. 1). In accordance with the structural - geological concept of Garrido - Megías (1973) it is situated in the central eastern part of the Montsec Nappe along the thrust fault of the Boixols - Coll de Nargó Anticline, since Solé Sugrañes (1978) also known as "Coll de Nargó Fault", where the northern limb of the anticline is thrust over the southern limb (fig. 2). The eastern part of the fault has the appearance of a nappe-like overthrust, whereas between Boixols and Sallent the Jurassic and Cretaceous sequence of the anticlines southern limb, normally $1700 \mathrm{~m}$ thick, is reduced roughly to a $150 \mathrm{~m}$ zone of tectonic scales. West of Boixols the anticline converts to an undisturbed asymmetric southward inclined fold (Wil- lems, 1982). This area has been named St. Corneli Anticline by Gallemi et al. (1983) and Nagtegaal et al. (1983). This study aimed at reconstructing the paleogeographic situation (based on facial and paleontological data) during the deposition time of the marine late Upper Cretaceous. Further, the prevailingly non-marine Maestrichtian to early Tertiary "Garumnian" facies in the surroundings of the Boixols - Coll de Nargó Anticline (region of Boixols/Montanisell/Coll de Nargó) were investigated.

Investigations on lithofacies, sedimentology, environments, and biostratigraphy of the mentioned region have been published by Rosell (1967), Souquet (1967), Mey et al. (1968), Garrido-Megías (1973), Willems (1982), and Gallemi et al. (1983). Studies with special regard to the paleogeographic situation during Upper Cretaceous and Early Tertiary were carried out by Nagtegaal (1972), Rosell et al. (1972), Ghibaudo et al. (1973), Liebau (1973), and Nagtegaal et al. (1983). These publications, however, deal mainly with the

(*) Dr. Helmut Willems, Geologisch Paläontologisches Institut der Johaan Wolfgang Goethe-Universität, Senckenberg-Anlage 32-24, D-6000 Frankfurt am Main, BRD. 
Tremp area, in particular the northern adjacent region (Sant Corneli and Pobla de Segur) and mention little about the area east of the line Abella de la Conca/Isona.

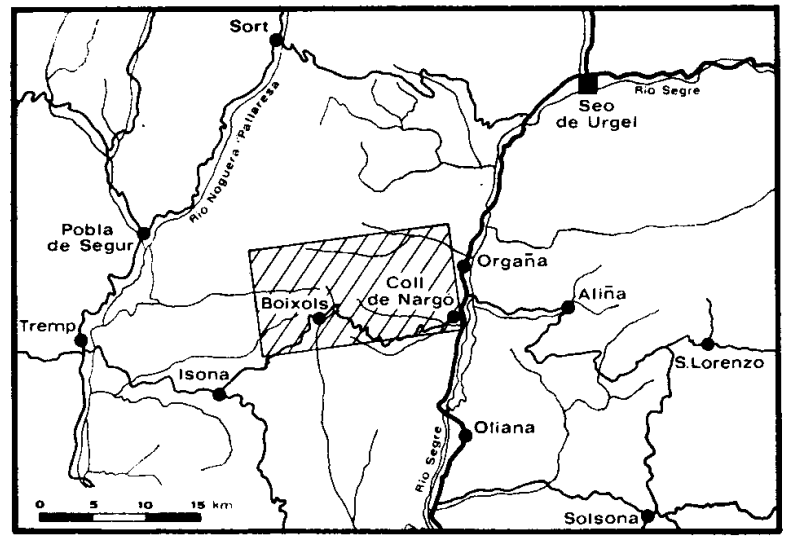

Fig. 1. - Sketch map showing the central Southern Pyreneans; studied area is indicated by hatched square.

\section{Description of lithostratigraphic units}

The examined sequences of late Cretaceous to early Tertiary deposits are subdivided into three lithostratigraphic formations.
Following terminology was introduced by Mey et al. (1968) and Nagtegaal (1972):

- Tremp Formation ("Garumnian" facies);

- Arén Sandstone Formation, sensu stricto;

- Arén Sandstone Formation, lower unit.

The facies and the sedimentary evolution of the formations have been studied in detail in eight sections (fig. 2), seven of them are represented in the columnar sections of fig. 3 .

\section{Arén Sandstone Formation, lower unit (Nagtegaal, 1972)}

The lower unit of the Arén Sandstone Formation (Nagtegaal, 1972), a member of the Arén Sandstone Formation defined by Mey et al. (1968), is represented in sections 1-6 of fig. 3. The sediments rest unconformably on grey-blue marls and nodular marly limestones containing few turbiditic layers. Because of their insignificant flysch character, these layers are regarded as transitional facies both between the carbonate turbidites, olistostromes, and marls of Vallcarga Formation (Mey et al., 1968) in the W ( $\mathrm{N}$ of Tremp area) and the marls and marly nodular limestones of the "Formación Perlés" (Solé Sugrañes, 1970) E of Rio Segre. In some locations, especially towards the W, the upper part of these marls shows many significant character analogies to the "Salàs marls Member" (Nagtegaal, 1972), the upper member of the Vallcarga Formation.

In the southern part of the investigated area, the lower unit of the Arén Sandstone totals approximately $250-300 \mathrm{~m}$, whereas it increases southward to more than $1000 \mathrm{~m}$ in

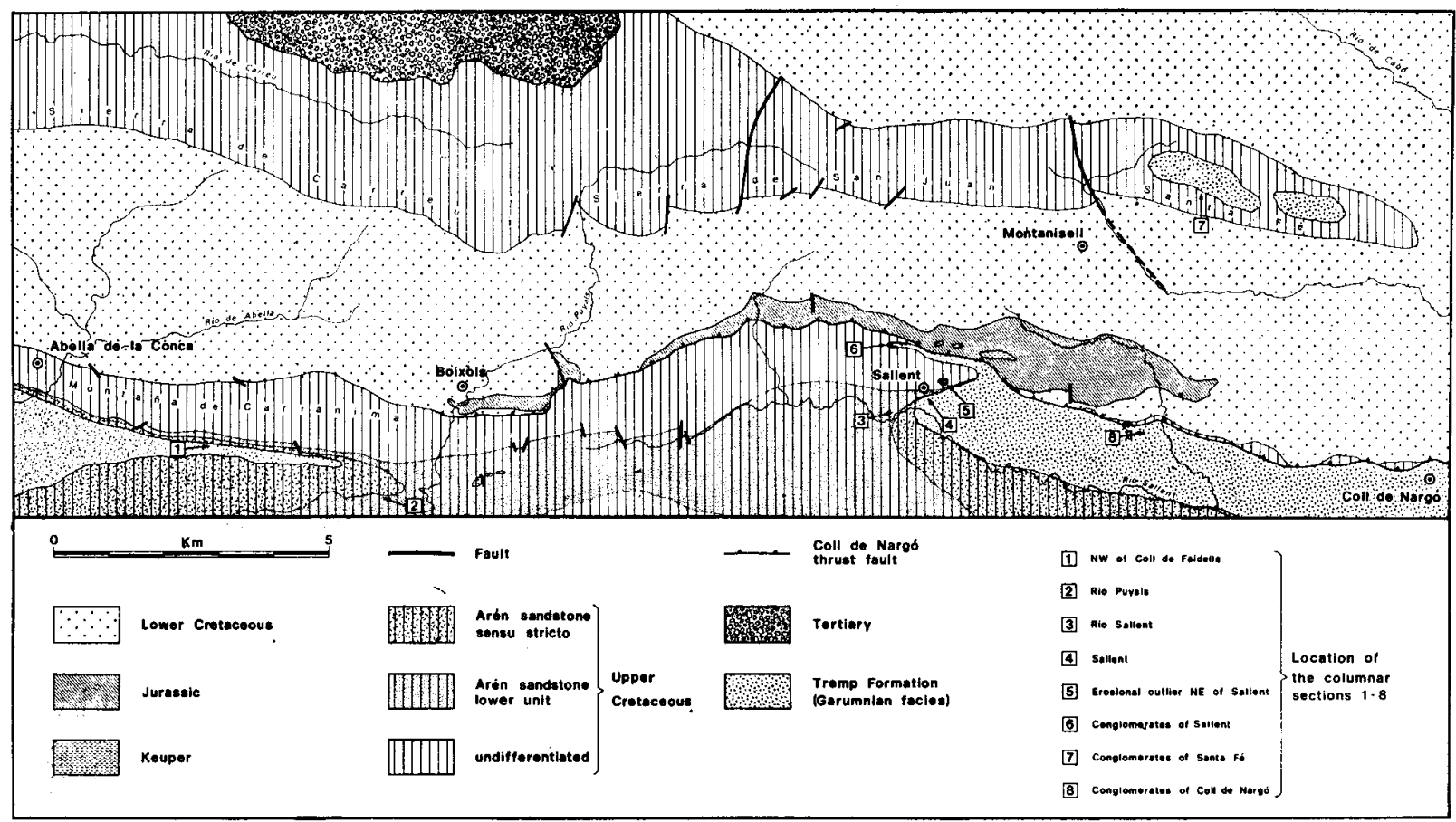

Fig. 2.-Simplified geological map of the Abella de la Conca - Coll de Nargó area (based on Willems, 1982) showing the locations of the studied sections 1-8. 
Valldarques. In this region the roof is built up by the Arén Sandstone sensu stricto. Contrary to the development in the southern region, the deposits are reduced to $4-15 \mathrm{~m}$ in the two recently discovered erosional outliers at the southern flank of Boixols-Coll de Nargó Anticline ( $N$ of Sallent sections 5-6 in fig. 2). There the roof consists of the Tremp Formation. Farther to the $\mathrm{N}$ the deposits taper out, and thus are missing in the Sierra de San Juan. (micritic and peloidal, intraclast-bearing biosparite, sometimes biomicrite). The content of siliclastic detritus varies from 2 to $10 \%$. The diversity of marine organisms is very high. Some layers contain numerous neritic benthonic fossils, such as orbitoidal foraminifera (Orbitoides sp., Lepidorbotoides sp., Siderolites sp.), well rounded fragments of (especially red) algae (Archaeolithothamnium sp.), chinoderms, bryozoans, Microcodium sp., rudists and other pelecypods. Thick lime-

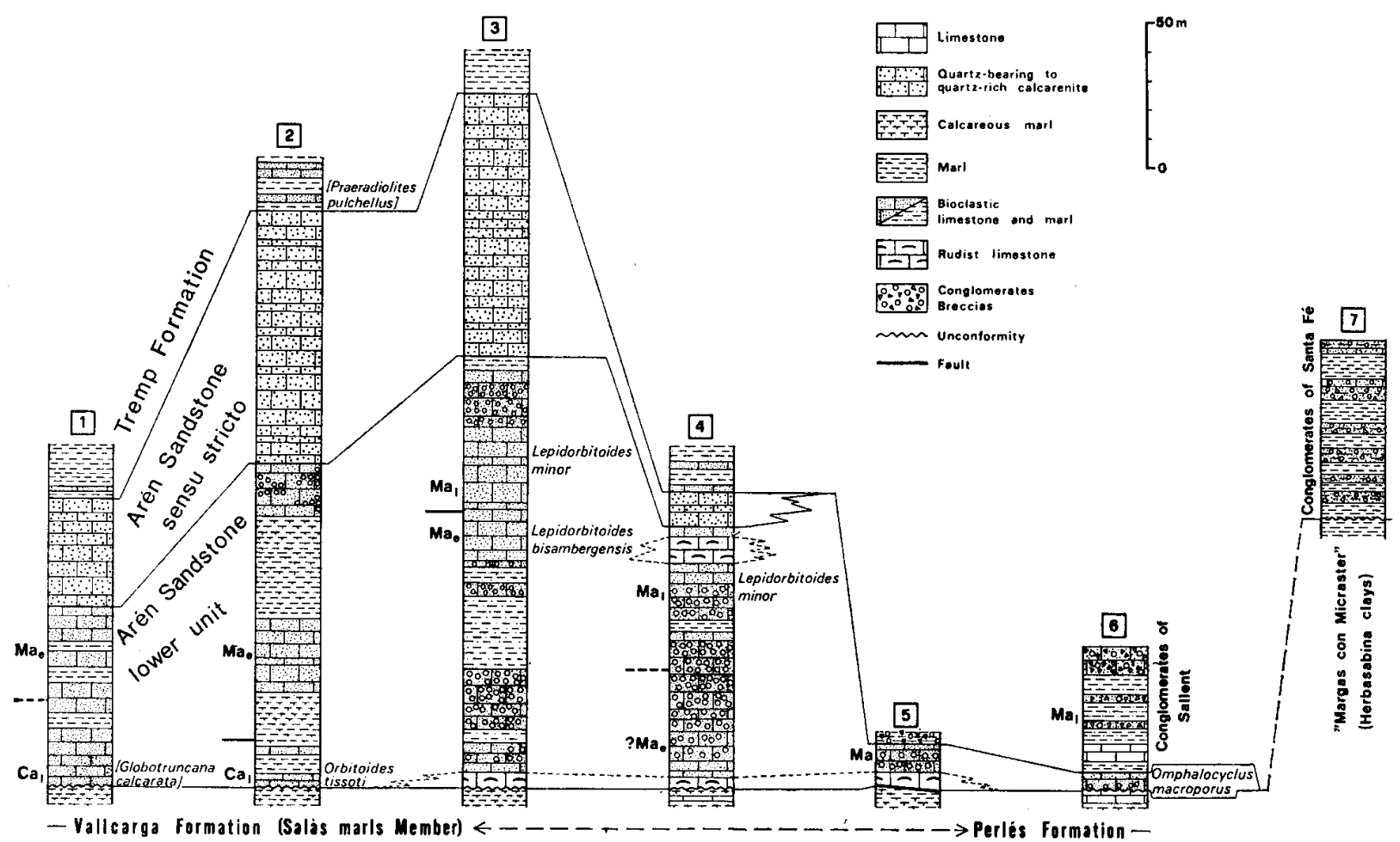

Fig. 3.-Lithological correlation of the formations and dating of the columnar sections 1-7 (locations of the sections are given in fig. 2). Ca $a_{1}$ : Late Campanian; Ma: Maestrichtian; $\mathrm{Ma}_{\mathrm{e}}$ : Early Maestrichtian; $\mathrm{Ma}_{1}$ : Late Maestrichtian.

The lower unit of the Arén Sandstone is described by Nagtegaal (1972) as a series of silty to fine sandy marls and calcarenites. However, in the region $E$ of Boixols (sections 3-6) the lithofacies deviate somewhat from Nagtegaal's report of the region $\mathbf{N}$ of the Tremp basin. For instance, at Sallent $3-5 \mathrm{~m}$ of rudist limestones containing Hippurites sp. and Praeradiolites sp. are intercalated at the base and at the top of the series (section 4). These rudists accumulate partly in rudist mounds, along with a few solitary corals (Cyclolites sp.), oysters (Lopha sp.), and rhynchonellids. Also particular to the region of Sallent are pebble-beds of variable thickness and horizontal extent. Their basal conglomerate contains components of the underlying marls and nodular marly limestones of Campanian age. Farther upwards in the sequence the assemblage of pebbles becomes more polymict, constituted by Palaeozoic lydites, limestones of Coniacian and Santonian age as cropping out in the Sierra de San Juan - Carreu and in the fault zone of the southern flank of Boixols - Coll de Nargó Anticline, as well as Lower Cenomanian limestones from erosional areas situated probably distant towards the $\mathbf{N}$.

On the microfacies, the yellow-brown and grey-blue marls for the most part show significant interfingerings between bioclastic grain- and packstones, and occasionally wackestones stone beds abundant with intensively reworked rud:st frag ments occur particularly in the lateral continuation of rudist mounds (rudist--biosparite).

The sedimentary evolution of the lower unit of Arén Sandstone reflects the var ous environments of an open - marine platform (shallow to deeper subtidal). The deposits alternate between offshore and nearshore conditions, influenced by diverse neritic and terrigeneous material. In the eastern area (Sallent) littoral deposits with conglomeratic deltaic fans and submarine channel fillings are found, thus indicating a regressive phase which began in Late Cretaceous throughout the entire southern Pyrenees (Nagtegaal, 1972).

The age of the lower unit of Arén Sandstone is diachronous, as denoted by benthonic foraminifera and rudists. Near Coll de Faidella, Orbitoides tissoti SCHLUMBerger (fig. 4e-f) indicates Campanian (Neumann, 1980), whereas the accompanying frequent species Orbitoides media D'ARCHIAC (fig. 4a-d) is also known from Maestrichtian. In the region of Sallent, however the deposits can be dated as Maestrichtian by Hippurites radiosus Des MouLINS, Hippurites lamarc$k i$ (BAYLE), and Praeradiolites cylindraceus (DEs Moulins), and by the foraminifera Siderolites calcitrapoides LAMARCK (fig. $4 \mathrm{~g}$ ) and Fascispira colomi SILvesTrI. According to Van Gorsel (1975) and Neumann (1980) a more precise dating 
is possible using Lepidorbitoides bisambergensis (JAEGER), (fig. $4 \mathrm{i}, \mathrm{k}$ ), which continues until Early Maestrichtian and possibly even to the beginning of Late Maestrichtian, and Lepidorbitoides minor (SCHLUMBERGER), (fig 41), which is characteristic of Late Maestrichtian. Uppermost Maestrichtian is affirmed by Omphalocyclus macroporus (LAMARCK), (fig. $4 \mathrm{~h}$ ) in section 6 (fig. 3), whereby Lepidorbitoides socialis (LEYMERIE) and Orbitoides apiculata SCHLUMBERG, also typical of this time (Van Gorsel, 1975; Neumann, 1980), have not been found.

The dating of the lower unit of the Arén Sandstone and of the underlying grey-blue marls and nodular marly limestones, which contain large amounts of planktonic foraminifera, indicates a hiatus between the two lithological units. The base of the lower Arén Sandstone unit, which rests unconformably on the offshore marls (transitional facies between Vallcarga Formation and "Formación Perlés"), is dated as Late Campanian in the W (sections 1-2) and as Early to Late Maestrichtian in the E (sections 4-6). The top of the underlying maris is uppermost Campanian in the $\mathrm{W}$ as determined with Globotruncana calcarata Cushman, and middle to higher Campanian in the E, according to Globotruncana elevata (BROTZEN), G. stuartiformis DALBIEZ, and G. caliciformis (DE LAPPARENT). Thus, the stratigraphic gap beco-

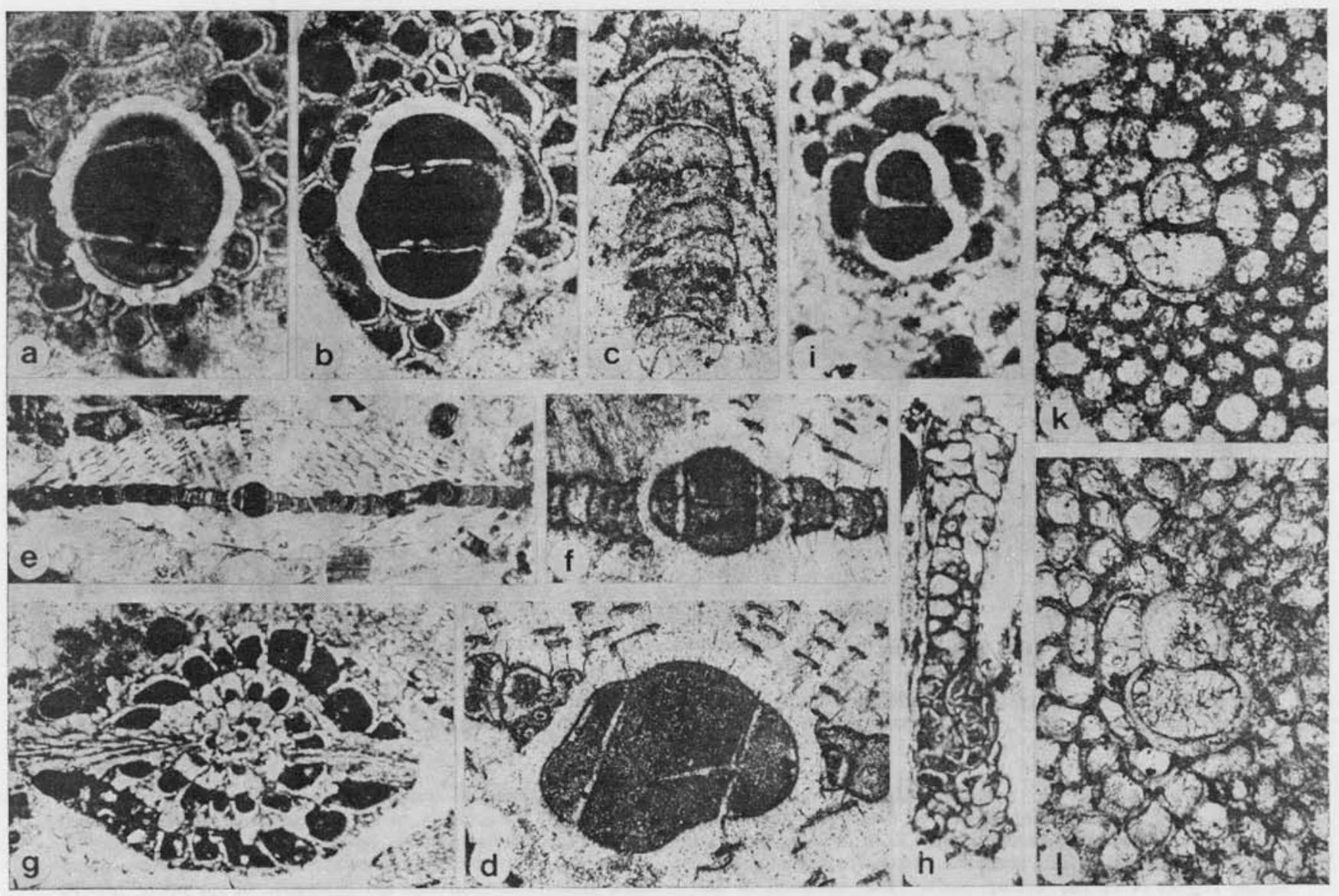

Fig. 4.-a: Orbitoides media (D'ARCHIAC), horizontal section showing trilocular embryonic chamber $(400 \times 340 \mu)$ with six epi-auxiliary chambers; X70. Late Campanian-Maestrichtian, Sallent (Prov. Lérida).

b: $O$. media, horizontal section showing trilocular embryonic chamber $(400 \times 330 \mu)$ with eight epi-auxiliary chambers; X70.

c: $O$. media, vertical section of equatorial chambers which are connected by $3-4$ stolons; $X 80$.

d: $O$. media, vertical section showing larger quadrilocular embryonic chamber $(540 \times 360 \mu)$ than Orbitoides tissoti SCHLUMBerger (f), few equatorial chambers, and three stolons; X70.

e: Orbitoides tissoti SCHLUMBERGER, vertical section showing embryonic chamber, equatorial chambers, and the typical Orbitoides lateral chambers; X25. Late Campanian, Coll de Faidella (Prov. Lérida).

f: $O$. tissoti with quadrilocular embryonic chamber $(300 \times 240 \mu) ; \mathrm{X} 70$.

g: Siderolites calcitrapoides LamarcK; X30. Maestrichtian, Sallent (Prov. Lérida).

h: Omphalocyclus cf. macroporus (LAMARCK); X25. Uppermost Maestrichtian, Sallent (Prov. Lérida).

i, k: Lepidorbitoides bisambergensis (JAEGER), horizontal sections showing embryonic chambers (Protoconch $=105 \mu$ Deuteroconch $=140 \mu$ ) without adauxiliary chambers; $\mathrm{x}$ 100. Late Campanian - Early Maestrichtian, Coll de Faidella (Prov. Lérida).

1: Lepidorbitoides minor (SCHLUMBERGeR), horizontal section showing embryonic chambers (Protoconch $=120 \mu$, Deuteroconch $=175 \mu$ ) with one adauxiliary chamber; X100. Late Maestrichtian, Sallent (Prov. Lérida). 
mes larger from $W$ to $E$, as well as to the $N$ in the approach to the southern flank of the Boixols - Coll de Nargó Anticline. W of Montesquiú and towards the S (Valldarques) the unconformity ceases.

\section{Arén Sandstone Formation, sensu stricto (Nagtegaal, 1972)}

The Arén Sandstone sensu stricto as defined by Nagtegaal (1972) is the upper member of the Arén Sandstone Formation (Mey et al., 1968). These deposits decrease in thickness from S (90 m at Rio Puyals, section 2) to N (15 m at Sallent, section 4) and finally taper out farther to the $N$ (sections 5-6). The reddish-brown sandstones and detrital limestones, which form a marked ridge in the landscape, are well (medium to thick) bedded, and show parallel-lamination and cross-bedding. Especially at the top of the sequence one finds fine-sandy and silty sandstones and marls with current ripples. The sediments rest on the lower unit of the Arén Sandstone as a deposit, displaying erther an abrupt increase of medium- to very coarse-grained terrigeneous quartz (coarsening-upwards sequence at Coll de Faidella, Nagtegaal $e t$ al., 1983) or a successive increase of silty to fine-grained quartz (Sallent).

These quartz - bearing and even quartz - rich calcarenites (pack-and grainstones) and calcareous sandstones contain debris of open - marine organisms (large foraminifera, Corallinacean algae, echinoids, rudists, bryozoans). They are considered as high - energetic shallow - marine coastal deposits (shallow subtidal to intertidal) with significant terrigeneous clastics influence (see also Ghibaudo et al., 1973; Nagtegaal et al., 1983). Marly intercalations with oysters and Characean algae in the upper part of the sequence indicate the change to lagoonal and finally limnic-lacustrine conditions during the subsequent "Garumnian" facies.

Orbitoides media D'ARChIAC (fig. 4a-d), Siderolites calcitrapoides LAMARCK (fig. 4g), and Lepidorbitoides sp., confirm that the Arén Sandstone sensu stricto is Maestrichtian. A more precise dating is presented by Liebau (1973) from the Barranco de la Posa. There the Arén Sandstone Formation is situated below a horizon with Praeradiolites pulchellus (VIDAL), which indicates a lowermost Maestrichtian age. However, deposits from the surroundings of Sallent are found to be Late Maestrichtian, according to the dating of the under ying lower unit of the Arén Sandstone using Lepidorbitoides minor (SCHLUMBERGER) (fig. 4l).

\section{Tremp Formation (Mey et al., 1968)}

The continental red beds of the Tremp Formation are also known by the facies term "Garumnian" as defined by Leymerie (1862). A discussion concerning usage of the term and of its locally differing stratigraphic range is found in Gutiérrez et al. (1979). At the southern flank of the Boixols - Coll de Nargó Anticline these lacustrine and fluviolacustrine deposits, in the lower part locally intercalated by marine limestones with rudists, rest either on top of the lower unit of the Arén Sandstone (sections $5-6$ ) or on top of the Arén Sandstone sensu stricto (sections 1-4).

Concerning the heterochronous beginning of the "Garumnian" facies, the regression and trasition to a "semi-arid coastal alluvial plain" (Nagtegaal et al. 1983) environment began earlier in the region of Isona than at Sallent. In the western part of the studied area (Barranco de la Posa), the base of the "Conca-Garumnian" has been dated (Liebau, 1973) as lowermost Maestrichtian by Praeradiolites pulchellus (VIDAL). On the other hand, at the northernmost occurrence $N$ of Sallent (section 6) the position of the boundary seems to be stratigraphically higher, as the directly underlying lower unit of the Aren Sandstone contains $\mathrm{Om}$ phalocyclus macroporus (LAMARCK) which is typical of the uppermost Maestrichtian (Neumann, 1980).

In the region of Coll de Nargó (section 8), the Tremp

Formation in general can be divided into three members:

- Upper Garumnian: $250 \mathrm{~m}$ poymict conglomeratic layers with intercalations of brik-red marls and grey micritic limestones, known as "Conglomerados rojos de Coll de Nargó" (Garrido-Megías, 1973).

- Middle Garumnian: $\mathbf{4 0 0} \mathrm{m}$ reddish-brown marls (mudstones with burrows) with few intercalated conglomeratic and arenitic limestones.

- Lower Garumnian: $60 \mathrm{~m}$ grey marls containing ostracodes and charophyte oogonia. with intercalation of coal beds and of marine horizons with rudists and orbitoidal foraminifera.

The Lower Garumnian crops out in the Rio Sallent valley in the $E$ (sections 3-4) and the Coll de Faidella in the $W$ (sections 1-2), where it lithologically corresponds with the "Posa" unit of the "Conca-Garumnian" (Liebau, 1973) However, a development deviating from this is found $\mathbf{N}$ of Sallent (section 6) where the "Garumnian" concordantly overlies the lower unit of the Arén Sandstone. The lithology of this $30-70 \mathrm{~m}$ early "Garumnian" differs facially from the above described Lower Garumnian in its contents of brick-red marls with polymict conglomerates and breccias, intercalating with limestones (algal mudstone). This lithological unit is called Conglomerates of Sallent (fig. 3).

The similarities between the Conglomerates of Sallent and the "Conglomerados rojos de Coll de Nargó" (Upper Garumnian), relative to the lithofacies and the same structural geological appearance along the southern margin of the Coll de Nargó thrust fault, led to the conclusion that they are of the same genesis (Souquet 1967; Plaziat, 1972; Garrido-Megías \& Ríos, 1972; Garrido-Megías, 1973). Nevertheless there are still clear differences between the two occurrences as to the following three topic:

1) Stratigraphy: The Conglomerates of Sallent are Maestrichtian, possibly uppermost Maestrichtian as concluded from the dating of the underlying lower unit of the Arén Sandstone by Omphalocyclus macroporus and from the occurrence of dinosaur aggs throughout this sequence. The "Conglomerados rojos de Coll de Nargó" are Paleocene and can be compared to the Conglomerates of Talarn that are of Montian age (Souquet, 1967; Garrido-Megías \& Ríos, 1972).

2) Lithology: Despite the similar lithofacies of the two units, their pebble spectra are different. The pebbles of the Conglomerates of Sallent come primarily from Coniacian and Santonian sources. The "Conglomerados rojos de Coll de Nargó" contain older Mesozoic pebbles, whereby large unsorted limestones and soft, easily destroyable marlstones with Orbitolina sp. of Aptian age (Urgonian facies) are of particular interest; this type of pebble has already been documented by Ríos (1951).

3) Contacts with older units along the Coll de Nargo thrust fault: The Conglomerates of Sallent as well as the "Conglomerados rojos de Coll de Nargó" are in contact with different Jurassic and Cretaceous formations of the southern limb of the Boixols - Coll de Nargó Anticline. In particular, the Upper Cenomanian - Lower Turonian limestones with Praealveolina sp. Misch (1934), Rosell (1967), and Souquet (1967) interpret this as fault contact, whereas Plaziat (1972), 
Garrido-Megías \& Ríos (1972), and Garrido-Megías (1973) regard the contact with the Praealveoline-limestone ("Santa Fé Limestones", Mey et al., 1968) as transgressive. Recent studies show, however, that the only unconformable contact along this fault zone exists between the Late Maestrichtian Conglomerates of Sallent and the grey-blue marls and nodular marly limestones of the lower part of the transtion facies between Upper Santonian - Campanian Vallcarga Formation in the $W$ and Perlés Formation in the $E$. Locally it was proved that the Conglomerates of Sallent rest tectonicagy undisturbed even upon Santonian Anserola Formation (Mey et al., 1968; also known as "Margas con Micraster", Rosell, 1967). In the actual outcrops, the basal conglomerate of the Conglomerates of Sallent consists mostly of marls and marly limestone pebbles of the above mentioned formations, fillinf up the extant relief with a depositional fabric. The contacts between the Paleocene "Conglomerados rojos de Coll de Nargó" and the underlying older, mostly tectonically isolated lithic units, are exclusively faulted and show fractured zones and polished surfaces. W of Coll de Nargó (section 8) the two sequences of Middle and Lower Garumnian are absent along this thrust fault because of shearings parallel to bedding faults.

A third Garumnian-like conglomeratic sequence in the eastern part of the Sierra de San Juan - Santa Fé Syncline (section 7 in fig. 2) must be considered for the "Conglomerados rojos de Coll de Nargó" and the Conglomerates of Sallent. These Conglomerates of Santa Fé (fig. 3) consist of up to $60 \mathrm{~m}$ of alternating brick-red marls, unsorted polymict breccias, and conglomerates with pebbles of different size ( $\mathrm{cm}$ to $\mathrm{dm}$ ), which rest in a lithologically clear unconform contact on grey marls and nodular marly limestones containing echinoids ("Margas con Micraster", Rosell, 1967). These deposits seem to be lithologically equivalent to the "Herbasabina clays" which reach up to Campanian and/or the lithostratigraphic unit "Prats de Carreu" (Gallemi et al., 1983). The conglomerates as well as the underlying marls are both slightly folded forming a syncline (San Juan - Santa Fé Syncline, Willems, 1982).

Thus, it must be asked whether this unconformity and the above discussed unconformity at the base of the "Garumnian" deposits at the southern margin of the Coll de Nargó thrust fault are related. The similar lithological habitus and the identical folding style suggest that the Conglomerates of Santa Fé correlate with the Paleocene "Conglomerados rojos de Coll de Nargó" (Dalloni, 1930; Ríos, 1951; Souquet, 1967; Plaziat, 1972; Garrido - Megías, 1973). Plaziat and Garrido - Megías deduced a tectonic - stratigraphic analogy between these occurrences, the contact between the "Conglomerados rojos de Coll de Nargó" and the (lower) Upper Cretaceous limestones at the Coll de Nargó thrust fault, and the contact between the Conglomerates of Santa Fé and the underlying Santonian-Campanian marls and marly limestones represent an unconformity caused by the same tectonic event.

However, this interpretation must be put to question, as not only the age of the Conglomerates of Santa Fé is still uncertain, but also the chronological connection of the two deposits.

Referring to the unconformable superposition upon Santonian-Campanian sediments containing echinoids, the Conglomerates of Santa Fé are more comparable to the Late Maestrichtian Conglomerates of Sallent (section 6 in fig. 3). There are remarkable analogies in the lithology (e. g. spectrum of pebbles) as well as in the folding style of these two conglomeratic "Garumnian" deposits, which probably occurred during the Pyrenean folding phase. Nevertheless, it cannot yet be determined whether the Conglomerates of Santa Fé correlate with the Conglomerates of Sallent or with the
"Conglomerados rojos de Coll de Nargó". This problem cannot be resolved until the Conglomerates of Santa Fé have been dated by biostratigraphical means.

\section{The paleogeographic situation in the region of Boixols-Coll de Nargó as a result of the anticline uplift in uppermost Cretaceous}

The described lithostratigraphic units are characterized by differentiation and interfingering of facies, by reduction of thickness from $S$ to $N$, respectively by their tapering out towards the southern flank of the Boixols - Coll de Nargó Anticline. This sedimentation pattern is governed by synsedimentary tectonics which resulted in an uplift of the anticline area and of areas adjacent to the $\mathbf{N}$ during Upper Campanian, Maestrichtian, and lowermost Tertiary (Danian). Thus, these observations established an eastern continuation of the so-called "Sant Corneli Island" (Nagtegaal et al., 1983), which in Campanian time existed on the northern margin of the Tremp basin. The sedimentation history at the southern flank of the anticline structure, influenced by lifting and wear is demonstrated by N-S sections of the Sallent region (fig. 5).

First indications of an uplift of the Boixols - Montanisell - Coll de Nargó area are discerned during the (Upper) Campanian i. e., the time of beginning regression in the South--Central Pyrenees. This uplift resulted in an unconformity ("discordancia intraCampaniense", Garrido-Megías \& Ríos, 1972). The unconformity seems to be restricted to the Boixols Coll de Nargó Anticline, its western continuation ("Sant Corneli Anticline", Nagtegaal et al., 1983) and their close surroundings. West (W of Montesquiú) and south (Valldarques) of this denudation area ("island") the unconformity disappears. South of the anticline high existed an E-W running basin within which a continuous shallow (to deeper) subtidal marine sedimentary sequence developed.

The lower unit of the Arén Sandstone then approached the differential subsiding anticlinale area from $S$ respectively SW over continuously older sediments of southward dipping Campanian to Santonian marls and nodular marly limestones (fig. 5a). Ocurrences of badly sorted conglomerates are derived from the islands ascertained in the north. A deltaic facies is confined for the lower part of the Arén Sandstone in the Sallent area. In the eastern part of the Tremp basin (Coll de Faidella) the "Arén Sea" already approached the Boixols-Montanisell-Coll de Nargó high during final Campanian, whereas in the Sallent region it arrived during Maestrichtian itime (fig. 3). The overlying Arén Sandstone sensu stricto has at this time advanced scarcely beyond section 4 at Sallent and it tapers out between sections 4 and 5 . Contrary to the region between Isona and Río Nogue- 
ra Ribagorzana where the age of the Arén Sandstone Formation is progressively younger from $\mathrm{E}$ to $\mathrm{W}$ (Ghibaudo et al., 1973), the Arén sediments of the subject area prove to become younger towards the east. sion of successviely older lithological units, presumably of a northern area during Danian time, is indicated by the pebble-spectrum of the "Conglomerados rojos de Coll de Nargó" (Upper Garumnian of Tremp Formation). Soft, easily destroyable marlsto-

$\mathbf{N}$

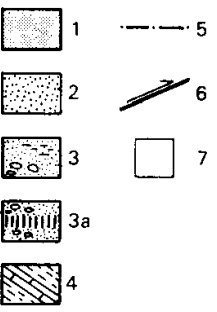

(a)

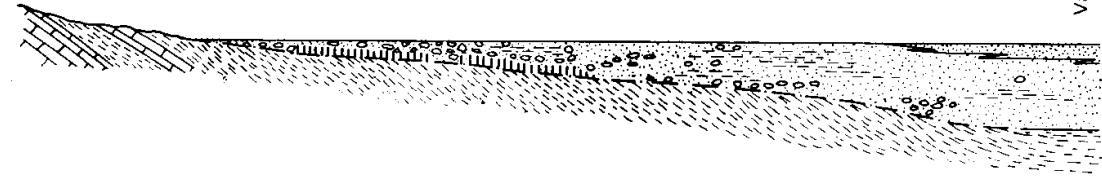

(b)
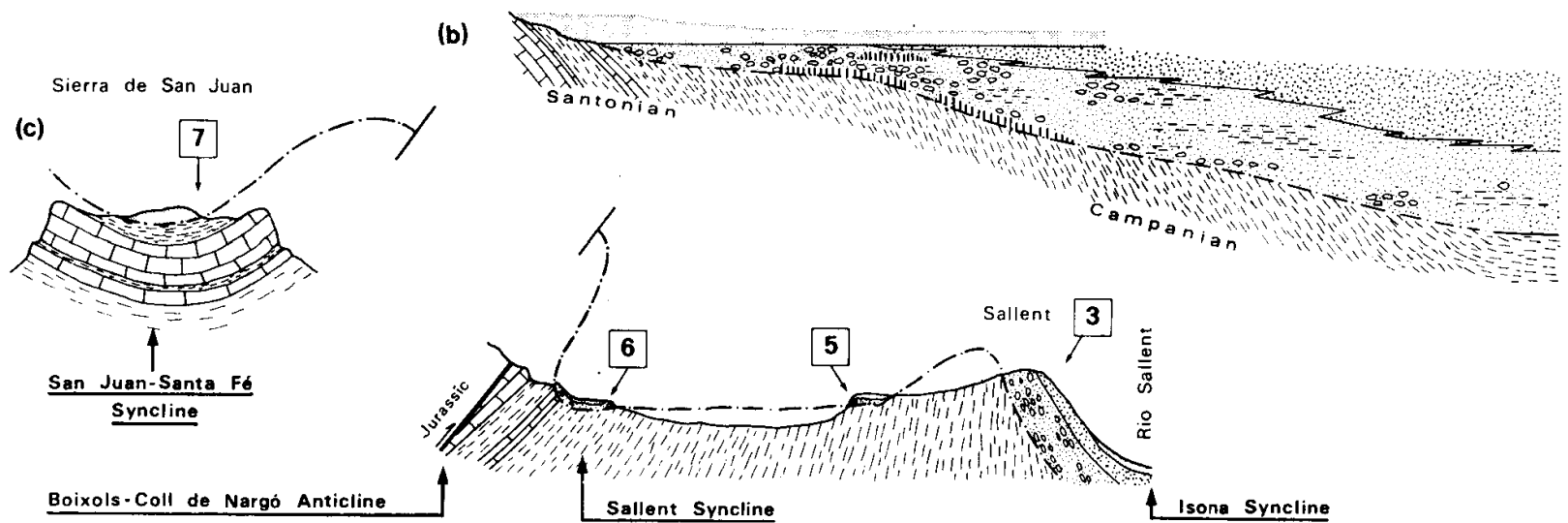

Fig. 5. Schematic cross sections in the region of Sallent showing the development of sedimentation south of Boixols Coll de Nargó Anticline during Late Campanian/Early Maestrichtian (a), Late Maestrichtian (b), and the present geological situation (c). 1: Tremp Formation ("Garumnian" facies); 2: Arén Sandstone Formation, sensu stricto; 3: Arén Sandstone Formation, lower unit; with rudist limestones at the base (3a); 4: Perlés Formation; 5: unconformity; 6: Coll de Nargó thrust fault: 7: locations of the lithological profiles 3-7.

In the Tremp basin the transition to the terrestrial "Garumnian" facies (Tremp Formation) took place during Early Maestrichtian. While thick layers of continental grey and red marls with some rudist bearing ingression layers were deposited there (Serie "Posa", Liebau, 1973), marine conditions continued in the Sallent area. N of Sallent (section 6), for instance, a last occurrence of marine limestones most likely of final Maestrichtian age is recorded in the lower unit of the Arén Sandstone. At this locality the directly overlying basal "Garumnian" Conglomerates of Sallent overlap farther northward than the lower unit of the Arén Sandstone and rest unconformably upon Santonian marls and marly limestones. Perhaps, the Conglomerates of Santa Fe (fig. 2) resting unconformably upon Campanian sediments, can also be interpreted as northern continuation of the "Garumnian" deposits of Sallent. Further uplift and ero- ne pebbles, containing Aptian Orbitolina, indicate a short transport from a nearby denudation area, presumably situated in the $\mathrm{N}$.

The position of the sections 3,5 , and 6 in fig. 5c and the differing angles of unconformity at the base of the Arén Sandstone Formation are caused by Pyrenean Phase movements during Eocene/Oligocene. Folding of strata, combined with overthrusting towards the south has caused relative movements between the sequences below and above the unconformity in the area $S$ of the Boixols - Coll de Nargó Anticline and its thrust fault zone. This has resulted in special fold structures in the region of Sallent (Willems, 1982), for example, a small syncline along the southern margin of the Coll de Nargó thrust fault (Sallent Syncline, fig. 5c). This syncline has falsely been interpreted by Plaziat (1972) as an tectonic overthrust scale. Another peculiarity is the erosional out- 
lier NE of Sallent (section 5), which lithologically links between the sections 4 and 6 . At this locality the lower unit of the Arén Sandstone rests horizontally upon $70^{\circ} \mathrm{N}$ reversely dipping marls and nodular marly limestones (transitional facies between Vallcarga Formation and "Formación Perlés"). The primary transgressive contact between the two units has been destroyed by shear movements.

The "Conglomerados rojos de Coll de Nargó" (Upper Garumnian) have consequently been turned vertically by Pyrenean Phase movements. They are in mechanic contact with older Mesozoic units, e. g. tectonic scales of Upper Cenomanian - Lower Turonian limestones. The underlying Lower to Middle Garumnian beds are detached by tectonic movements.

\section{References}

Dalloni, M.

1930. Etude géologique des Pyrénées catalanes (1 mapa 1:400.000). Ann. Fac. Sci. Marseille, 26, 1-373.

Gallemi, J.; Martínez, R. \& Pons, J. M.

1983. Coniacian-Maastrichtian of the Tremp Area (South Central Pyrenees). Newsl. Stratigr., 12, 1-17.

GarRido-Megías

1973. Estudio geológico y relación entre tectónica y sedimentación del Secundario y Terciario de la vertiente meridional pirenaica en su zona central. Tesis de Doctorado. 395 págs., Zaragoza.

Garrido-Megías, A. \& Ríos Aragües, L. M.

1972. Síntesis geológica del Secundario y Terciario entre los ríos Cinca y Segre (Pirineo central de la vertiente sur-pirenaica, prov. Huesca-Lérida). Bol. Geol. Min., 83, 1-47.

Ghibaudo, G.; Morelli, E.; Mutti, E.; Obrador, A.; Pons, J. M.; Ramasco. M. \& Rosell, J.

1973. Osservazioni sedimentologiche preliminaria sulle Arenarie de Arén (Cretácico Superiore) tra Isona e il río Noguera Ribargozana (Prepirinei Spagnuoli) (1). Boll. Soc. Geol. It., 92, 529-540.

GoRsel, J. T. VAN

1975. Evolutionary trends and stratigraphic significance of the Late Cretaceous Helicorbitoides - Lepidorbitoides lineage. Utrecht Microp. Bull., 12, 1-99.

GutiérRez, G. \& Robles, F.

1979. Consideraciones sobre la utilización del término "Garumniense" en la Cordillera Ibérica. Cuadernos Geol. Ibérica, 5, 385-405.

LeYmerie, A.

1862. Apercu géognostique des Petites Pyrénées et particulièrement de la montagne d'Ausseing. Supp. au Bull., S. G. F.: 2-20.

Liebau, A.

1973. El Maastrichtiense lagunar ("Garumniense") de Iso- na. XIII Coloq. Eur. Micropaleont. (España): 87-112, Madrid (ENADIMSA).

MeY, P. H. W; Nagtegall, P. J. C.; Roberti, K. J. \& HarteVelt, J. J. A.

1968. Lithostratigraphic subdivision of post-Hercynian deposits in the South - Central Pyrenees, Spain. Leid. geol. Meded., 41, 221-228.

MISCH, P.

1934. Der Bau der mittleren Südpyrenäen. Abh. Ges. Wiss. Göttingen, math. phys. Kl., 3, 1-68; Berlin.

Nagtegahl, P. J. C.

1972. Depositional history and clay minerals of the Upper Cretaceous basin in the South-Central Pyrenees, Spain. Leid. Geol. Meded., 47, 251-275.

Nagtegaal, P. J. C.; Vliet, A. van \& Brouwer, J.

1983. Syntectonic coastal offlap and concurrent turbidite deposition: the Upper Cretaceous Arén sandstone in the South-Central Pyrenees, Spain. Sediment. Geol., 34, 185-218.

Neumann, $M$.

1980. Observations micropaléontologiques à propos du Campanien et du Maastrichtien. $N$. Jb. Geol. Paläont., Mh., 1980, 417-427.

Plaziat, J. C.

1972. Précisions nouvelles sur la position stratigraphique et structurale des conglomérats à ciment rouge de Coll de Nargó (prov. de Lérida, Espagne). C. R. Acad. Sci. Paris, 274, 2431-2433.

Ríos, J. M.

1951. Estudio geológico de la zona de Coll de Nargó. Bol. Geol., 63, 1-96.

Rosell, J.

1967. Estudio geológico del sector del Prepirineo comprendido entre los ríos Segre y Noguera $\mathrm{Ri}$ bagorzana (prov. de Lérida). Pirineos, 21, 9-214.

Rosell, J.; Obrador, A. y Pons, J. M.

1972. Significación sedimentológica y paleogeográfica del nivel arcilloso con corales del Senoniense superior de los alrededores de Pobla de Segur (prov. de Lérida). Acta Geol. Hisp., 7, 7-11.

Solé Sugrañes, L.

1970. Estudio geológico del Prepirineo entre los ríos Segre y Llobregat. Tesis Fac. Cienc., 1-495, Barcelona.

1978. Gravity and compressive nappes in the Central Southern Pyrenees (Spain). Amer. J. Sci., 278, 609-637.

SOUQUET, $\mathbf{P}$.

1967. Lo Crétacé supérieur Sud-pyrénéen en Catalogne, Aragon et Navarre. Thèse doctorat Fac. Sci. Toulouse, 529 p.; Toulouse.

WILLEMS, $\mathrm{H}$.

1982. Stratigraphie und Tektonik im Bereich der Antiklinale von Boixols-Coll de Nargó. Ein Beitrag zur Geologie der Decke von Montsech (zentrale Südpyrenäen, NE-Spanien). Frankfurter geowiss. $A r b ., 2,1-335$.

Recibido el 16 de noviembre de 1984. Aceptado el 23 de marzo de 1985. 


\title{
NUEVOS SONDEOS DE INVESTIGACION GEOLOGICA EN EL AREA DE MADRID
}

\author{
J. P. Calvo Sorando (") y A. García Yagüe [**)
}

\section{RESUMEN}

Se describen en este trabajo las columnas litológicas correspondientes a tres sondeos de investigación geológica realizados durante el año 1983 en el casco urbano de Madrid. Dichos sondeos tienen como objetivo contribuir al análisis de la repartición de litofacies en el sector del subsuelo de Madrid, donde tienen lugar los principales cambios de facies que configuran el sistema deposicional durante el Mioceno medio en este área.

El sondeo SGOP-1 se ubica en la Avenida de Portugal, con una profundidad total de 256 metros. La columna obtenida consta esencialmente de depósitos arcósicos finos, con términos arcillosos y algunos niveles evaporíticos en su parte inferior.

El sondeo SGOP-2 está emplazado en el barrio de San Blas, con una profundidad de 203 metros y atraviesa tres unidades litoestratigráficas bien diferenciadas, en parte correlacionables con los niveles aflorantes al 'este del núcleo urbano. Una columna similar es obtenida en el sondeo SGOP-3, en Vallecas, con una profundidad final de 180 metros.

Se presenta un ensayo de correlación ientre estos nuevos sondeos y los datos previamente descritos en el subsuelo de Madrid.

Palabras clave: Mioceno, Cuenca de Madrid, Litofacies, Sondeos mecánicos, Sedimentación continental.

\section{Abstract}

Three new drillings, deeping from 180 to $260 \mathrm{~m}$, were holed in the urban area of Madrid during 1983. The drillings aimed to test the lithostratigraphic relationships within Miocene deposits that form the subsurface of this city.

Drilling SGOP-1 was placed in Av. Portugal and it dept until $256 \mathrm{~m}$. The stratigraphic sequences is made up mainly by arkosic sands and sandy-clayey deposits, throughing down greenish lutites and a few gypsum beds.

Drilling SGOP-2 was placed in San Blas. It dept until $203 \mathrm{~m}$ and it cutted three main lithostratigraphic units that might be correlated with nearby autcropping miocene deposits in eastern Madrid. At the same, drilling SGOP-3 cross over those units in Vallecas, southern Madrid. Herein, drilling stopped at $180 \mathrm{~m}$.

A correlation network may be stablished from these new data when they are compared with previous subsurface information of Madrid.

Key words: Miocene, Madrid Basin, Lithofacies, Well-Drillings, Continental Deposits.

\section{Introducción}

El reconocimiento geológico de áreas urbanas está muy limitado por la escasez de afloramientos. Este hecho resulta obviamente crítico en núcleos urbanos como el de Madrid, con una superficie construída y/o antropizada cifrable en algo más de $300 \mathrm{~km}^{2}$ (50\% de la extensión del término municipal), donde los afloramientos naturales son de pequeña magnitud e insuficientes para proporcionar una información geológica de detalle.

$\mathrm{La}$ obtención de información geológica en estas circuns- tancias puede encararse desde distintos puntos, entre los que inicialmente destacan las descripciones geológicas antiguas realizadas previamente a la etapa de gran expansión del suelo urbano, uno de cuyos términos máximos tiene lugar en Madrid a partir de los años sesenta. Ejemplo de esta información es la cartografía y memoria geológica realizada por Royo Gómez (1929), que constituye por su globalidad y minuciosidad en la descripción el mejor documento de esta época en cuanto al conocimiento geológico de Madrid, no existiendo una documentación de entidad similar hasta entrados los años setenta.

(*) Departamento de Petrología. Facultad de Ciencias Geológicas. Universidad Complutense. Madrid.

(**) Servicio Geologico de Obras Públicas, Avda. de Portugal, 11, Madrid. 
Asimismo, la configuración geológica de un área de estas características podría conseguirse por correlación con las zonas no urbanizadas próximas. Sin embargo, esta metodología facilita tan solo una aproximación, máxime cuando nos encontramos en áreas con sedimentos continentales caracterizados por frecuentes cambios laterales de facies.

En consecuencia, es clara la importancia que en las áreas urbanas tienen los datos suministrados por las técnicas de análisis del subsuelo (sondeos mecánicos, catas, perfiles geofísicos, ...) y la información sobre obras subterráneas, a pesar de su carácter relativamente puntual, pues proporcionan en muchos casos los únicos datos precisos sobre las características litoestratigráficas, petrológicas, hidrogeológicas o geotécnicas del área considerada.

En el término municipal de Madrid existen datos procedentes de dos tipos de sondeos. El primero engloba los de finalidad geotécnica, frecuentemente cortos o muy cortos, y que, además, tienen como característica general descripciones muy heterogéneas, al ser realizados por entidades o grupos muy diferentes, y estar enfocados a la cuantificación de las propiedades geotécnicas especificadas en el proyecto. No profundizan, y con frecuencia ni siquiera abordan, aspectos genéticos, cronoestratigráficos o petrológicos, salvo muy raras excepciones.

En el segundo grupo se incluyen los sondeos y pozos con finalidad hidrogeológica, con profundidades de hasta $350 \mathrm{me}$ tros, los cuales son realtivamente abundantes en la mitad norte del término municipal de Madrid. En éstos los objetivos también han condicionado las descripciones de los terrenos atravesados, estando más ligados al comportamiento hidrogeológico que al origen y naturaleza de los sedimentos.

Con independencia de informes inéditos realizados por el Servicio Geológico de Obras Públicas, Instituto Geológico y Minero, Laboratorio de Carreteras y Geotecnia, etc. ..., en algunas publicaciones se facilita información sobre sondeos de interés (Aguila, 1962; García Yaglie, 1973; Llamas y López Vera, 1975; Martínez Alfaro, 1978; ...), pero siempre con descripciones relativamente limitadas como base para la determinación de las grandes unidades litológicas de la zona.

De gran utilidad resultan los perfiles de sondeos de reconocimiento efectuados para el trazado de las líneas recientes del Metropolitano de Madrid (Escario, 1969; Iberinsa, 1972 ; Agroman, 1973; Laboratorio de Carreteras y Geotecnia; Geocisa, 1982; etc.), los cuales permiten, a pesar de su profundidad media de unos 40 metros, una visión bastante completa y detallada de la evolución lateral de las diferentes unidades.

Insistimos, sin embargo, en que el importante volumen de datos de columnas de sondeo existentes en el área de $\mathrm{Ma}$ drid adolece comúnmente de una cierta generalización en la descripción litológica, faltando el detalle en cuanto a determinados rasgos de índole petrológica o sedimentológica que pueden ser claves para una interpretación más ajustada de ese área y, de ahí, del sector de la cuenca del Tajo donde se ubica.

Este aspecto, junto con la ausencia de datos de sondeo en algunas zonas, a nuestro entender de fuerte relevancia para el conocimiento del subsuelo del casco urbano, motivó la planificación y realización de tres sondeos largos por parte del Servicio Geológico de Obras Públicas, como ayuda los estudios incluidos en el Convenio de Colaboración Técnica y Cultural para el Conocimiento de las Características del Suelo y Subsuelo del Término Municipal de Madrid, firmado en 1982 por diversos organismos (Ayuntamiento de Madrid, S.G.O.P., Facultad de Ciencias Geológicas. Universidad Complutense, I. G. M. E., COPLACO, Laboratorio de Carreteras y Geotecnia,...). La ejecución de dichos sondeos tuvo lugar entre los meses de junio v diciembre de 1983 perforándose un total de 640 metros. La exposición de los resultados obtenidos con estos sondeos de investigación geológica básica constituyen el objeto del presente trabajo, siendo una aportación de interés tanto por los datos en sí mismos como por la posibilidad que éstos ofrecen para encajar la información geológica de subsuelo hasta ahora existente.

\section{Rasgos generales de la geología de Madrid}

El núcleo urbano de Madrid se ubica en el sector noroeste de la Depresión o Fosa del Tajo, también denominada Cuenca de Madrid (Megías et al., 1980; Junco y Calvo Sorando, 1984), a unos 20 kilómetros al sur de los primeros afloramientos de materiales granitoides y metamórficos que constituyen el borde meridional del Sistema Central. Los sedimentos correspondientes a zonas de borde de estos macizos graníticos consisten en secuencias potentes de arcosas, que distalmente evolucionan en cambio lateral de facies a sedimentos lutíticos, arenas micáceas, carbonatos y depósitos evaporíticos (yeso \pm anhidrita y halita). Este cambio lateral de facies (Riba 1957) debe, sin embargo, ser matizado en cuanto que el relleno sedimentario mioceno de la cuenca de $\mathrm{Ma}$ drid tiene lugar en sucesivas unidades tectosedimentarias (Megías et al., 1980, 1983) o megasecuencias deposicionales (Torres et al., 1984) y no como un ciclo sedimentario único. En el área de Madrid aparecen representadas dos de estas unidades mayores del Mioceno (Unidad inferior y Unidad intermedia) (Alberdi et al., 1983; Calvo Sorando et al., 1984), que abarcan en edad desde el Mioceno inferior al Mioceno medio, habiéndose reconocido, de acuerdo con esta óptica, varias unidades cartográficas, que constituyen la base del más reciente de los mapas geológicos de Madrid (fig. 1).

La realización de los sondeos cuyos resultados se exponen en este trabajo ha servido para confirmar y delimitar con mayor precisión la distribución de estas unidades en el subsuelo del casco urbano, estableciendo las correlaciones entre ellas y su evolución lateral desde un punto de vista estratigráfico y sedimentológico. Obviamente, esta mayor precisión permite también el sentar unas bases más afinadas en cuanto a las características hidrogeológicas y geotécnicas de dicho subsuelo.

\section{Ubicación y descripción de los sondeos}

En el esquema geológico de la figura 1 se señala la ubicación dentro del casco urbano de los tres sondeos realizados. Los criterios utilizados para dicha ubicación pueden resumirse en los siguientes puntos:

- Los sondeos debían cortar el mayor número de unidades litológicas presentes en el área de Madrid, unidades previamente definidas en base al reconocimiento de superficie en las zonas aflorantes inmediatamente al sur y este del casco urbano.

- Las columnas litológicas deberían precisar la evolución, tanto en variación de espesores como en continuidad o desaparición y cambio litológico, de los niveles que caracterizan las unidades al sur de Madrid. Se persigue una evaluación en detalle de los cambios laterales de facies que tienen lugar en el subsuelo del casco urbano de Madrid (Martínez Alfaro, 1978; Alberdi et al., 1983; Calvo Sorando et al., 1983; Hoyos et al., 1984; Escario y Salinas, 1984), los cuales se patentizan al comparar la secuencia de materiales presentes en la parte sur y este con las homogéneas sucesiones arcósicas dispuestas en posiciones más próximas al borde granítico.

Hay que señalar que la ubicación última de cada uno de los sondeos viene condicionada por la existencia de un lugar protegido perteneciente al Ayuntamiento $u$ otro Organismo, circunstancia necesaria para la salvaguarda de la maquinaria de un cierto vandalismo urbano, asî como por las posibilidades de abastecimiento de agua en las tareas de perforación. La elección del punto viene también condicionada por la disponibilidad en esos lugares de espacio suficiente para la instalación de las balsas de lodo y almacenaje de testigos. 


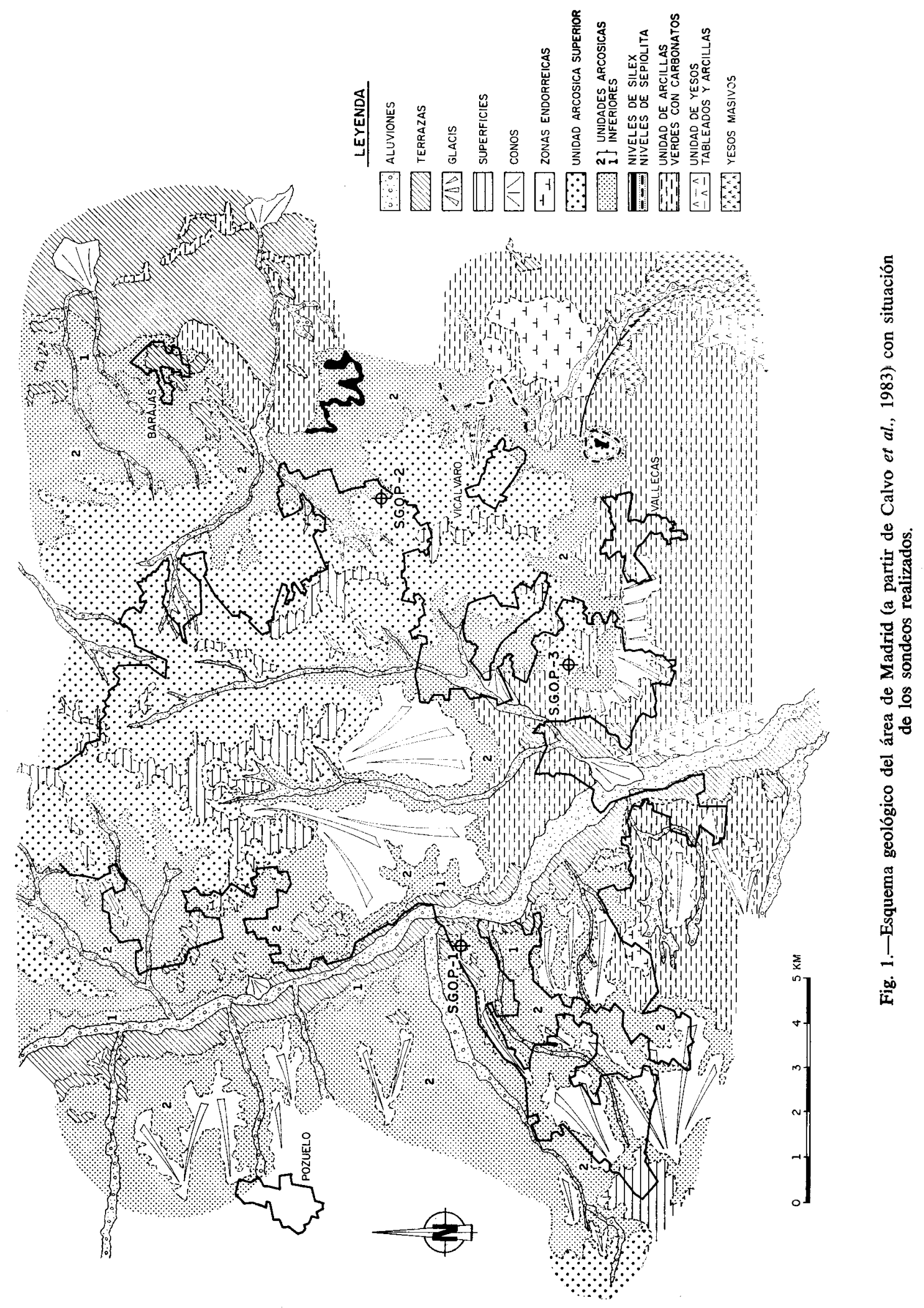


El método de perforación utilizado ha sido por rotación, con velocidad del orden de 250 revoluciones por minuto. En general se ha utilizado tubo sencillo y corona de widia, con diámetro de $\varnothing 92$ milímetros, en los primeros metros y tubo doble con corona de widia, de $\varnothing 74$ milimetros, en el resto. En los gráficos de las columnas de sondeos (figs. 2, 3 y 4) se disponen los valores de perforación diaria y la totalizada al origen, la profundidad del nivel de agua en el sondeo al comienzo y final de jornada, así como el porcentaje de recuperación de testigo. Asimismo, se representa en ellas el registro continuo de radiación natural, señalándose que la anchura total representa $0.100 \mathrm{MR} / \mathrm{H}$, el tiempo de integración de $T_{\mathrm{g}}=3 \mathrm{seg}$. y la velocidad entre $3-4 \mathrm{~m} . / \mathrm{mi}$ nuto (control manual).

\section{Sondeo S.G.O.P.-1}

Su emplazamiento fue llevado a cabo en la zona de talleres del Servicio Geológico de Obras Públicas, junto a la Avenida de Portugal. La embocadura del sondeo se sitúa a la cota topográfica 623 metros. Se perforaron un total de 25.6 metros con obtención de testigo continuo, realizándose entubación hasta los 111,75 metros con $\varnothing 110$ milímetros.

La columna litológica obtenida en este sondeo presenta a grandes rasgos una relativa homogeneidad, siendo destacables, de techo a muro, los siguientes aspectos (fig. 2):

- Presencia de un primer nivel, de 7,70 metros de espesor, constituido, en parte, por vertidos y escombros y en parte por depósitos posiblemente correspondientes a la terraza + 25-30 metros, de edad Pleistoceno medio, del Manzanares. La baja recuperación de testigo en este tramo impide una mejor caracterización de los espesores relativos de vertidos y terraza, así como de las facies de depósitos de terraza presentes.

- Por debajo de la discordancia erosiva de estos niveles cuaternarios se dispone una sucesión monótona de arenas arcósicas arcillosas y arcillas más o menos arenosas, de tonos pardos a rojizos, localmente con abundantes nódulos carbonáticos. Los rasgos distintivos de estos niveles son la ordenación bastante neta en secuencias granodecrecientes, con desarrollo de paleosuelos calcimorfos (costras masivas, nodulosidad, restos de rizolitos, ...), silicificaciones locales y evidencias de hidromorfismo. Este conjunto de facies son interpretados como depósitos distales de los abanicos aluviales arcósicos $o$, en sentido más genérico, como facies de orla distal de abanico con predominio de sedimentación lutítica-limosa afectada por fuertes procesos de edafización.

Aunque estas características se mantienen en toda la columna litológica, su presencia es más neta, en relación con otras facies, en los 125 primeros metros del sondeo.

- El resto de la columna litológica presenta, como variación a los tramos anteriormente descritos, una mayor frecuencia de intercalaciones de lutitas verdosas, comúnmente muy bioturbadas por raíces $\mathrm{y} / \mathrm{o}$ gusanos, entrada de niveles de arenas micáceas (biotita) muy característicos, y la aparición de lutitas grises y carbonatos (dolomita + magnesita) finamente laminados. Esta última litofacies, presente de forma episódica en los últimos 70 metros del sondeo, constituye una litología muy característica de los depósitos evaporíticos observados algo más al sur.

La presencia de niveles netamente evaporíticos en la columna queda reducida a tres pequeños niveles de yeso intercalados entre lutitas de tonos verdosos y grises hacia los 240 metros de profundidad.
Aparte de los rasgos reseñados, es de mencionar el hallazgo de una mandíbula de Lagopsis peñai, en excelente estado de conservación, en un testigo de lutitas negras extraído a los 214 metros de profundidad.

Desde el punto de vista de la mineralogía de las arcillas (ver fig. 2), cabe señalar su escasa variación a lo largo de la columna, con predominio de las esmectitas (alrededor del $70-75 \%)$ sobre los minerales del grupo de las illitas (0-30\%) y muy escasa presencia de caolinita. La sepiolita es localmente abundante. En cuanto a los minerales pesados, se registran muy pocas variaciones, con representación a lo largo de toda la columna de la asociación constituida por apatito, epidota, turmalina y circón como granos más abundantes.

\section{Sondeo S.G.O.P.-2}

Su emplazamiento fue llevado a cabo en el Polideportivo de San Blas. La embocadura del sondeo se sitúa a una cota aproximada de unos 680 metros, habiéndose perforado un total de 203 metros con extracción de testigo continuo. La perforación se realizó con tubo sencillo y corona de widia hasta los 22 metros y con tubo doble el resto. Se efectuó entubación hasta los 29 metros.

La columna litológica obtenida (fig. 3) muestra la superposición en este punto de tres unidades litoestratigráficas características del entorno meridional de Madrid. Unicamente los siete primeros metros corresponden a vertidos arcósicos y otros depósitos antrópicos. El primer nivel claramente de edad Terciario consiste en un banco de sílex marrón claro, que puede ser correlacionado con niveles similares aflorantes algo más al este, en las canteras adyacentes al barrio de San Blas.

La descripción de las unidades anteriormente señaladas es, de forma resumida, la siguiente:

\section{Unidad de arcosas con sílex y sepiolita}

Es cortada entre los 7 y los 43 metros de profundidad. Aparte de los bancos de sílex y arcillas situados a su techo, esta unidad aparece compuesta por una sucesión monótona de niveles arcósicos y arcillas marrones-rojizas arenosas. Hacia los 30 metros de profundidad se presenta un tramo muy arcilloso donde se distinguen al menos dos bancos gruesos de sepiolita, que se correlacionan con los explotados al este de San Blas. La asociación de facies descrita se interpreta como propia de zonas distales de los abanicos arcósicos con procesos de edaficación sobreimpuestos. Los niveles de sepiolita se interpretan como resultantes de la policondensación de suelos (Megías et al., 1982), mientras que los bancos silíceos que coronan la unidad corresponderían a encostramientos (silcretas).

Unidad de lutitas verdes con carbonatos y arenas micáceas

Se extiende con bastante homogeneidad hasta los 97 metros de profundidad. Son rasgos característicos de la unidad los niveles de lutitas masivas, en general fuertemente bioturbadas $\mathrm{y}$ con restos de vegetales macerados, las intercalaciones de lechos finos de arenas micáceas en secuencias granodecrecientes a arcillas, y la presencia de algunos niveles carbonáticos de ambiente palustre.

\section{Unidad de yesos tableados y arcillas}

Constituye el resto de la columna obtenida en el sondeo. Salvo algunos tramos con lutitas de tonos verdosos bioturbadas, es predominante en toda la sección una alternancia monótona de lutitas grises laminadas y pasadas de yesos con estructura nodular. Las lutitas presentan laminación milimétrica incluyendo algunos nivelillos de carbonatos (magnesita y dolomita). Sólo de forma local los yesos se presentan en bancos de hasta 20-30 centímetros de espesor. Hacia los 


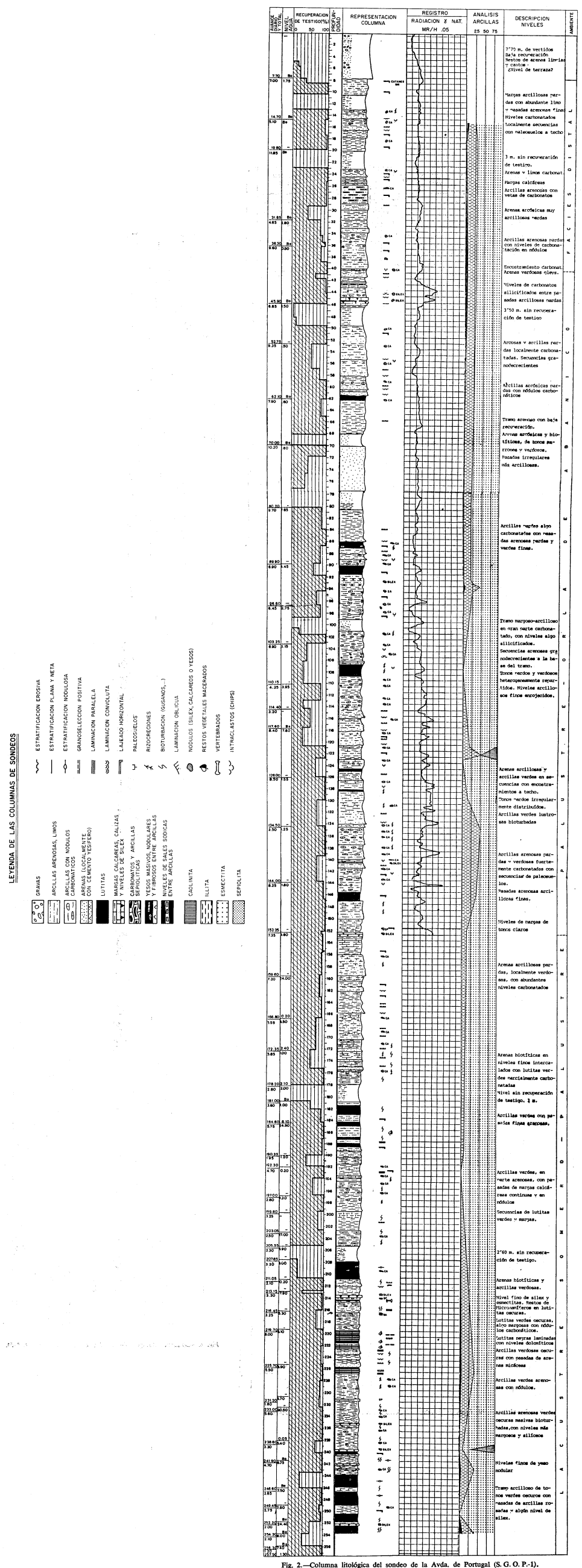




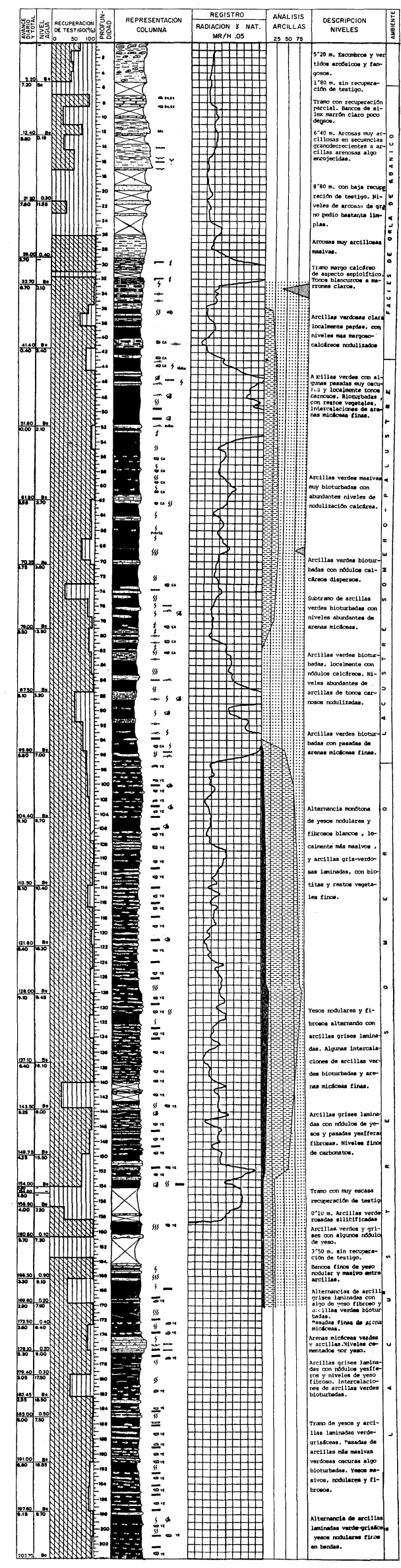

Fie. 3.-Columna litologica del sondeo del Polideportivo de San Blas (S. G. O. P.-2).

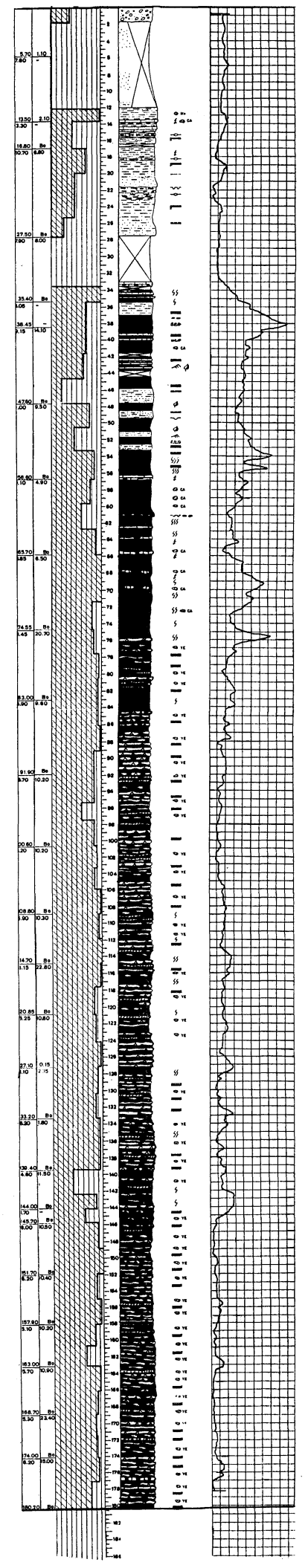

Fig. 4.-Columna litologica del sondeo de Vallecas (S. G. O. P.-3). 
174 metros de profundidad resalta la intercalación entre las facies anteriores de algunos bancos de arenas micáceas cementadas por yeso.

La mineralogía de arcillas (fig. 3) refleja de forma bastante unívoca las diferencias litológicas entre las unidades presentes en la columna. Así, la unidad de yesos tableados inferior muestra un incremento acusado del porcentaje de illitas en relación con el alto porcentaje de esmctitas característico de la unidad de arcillas verdes situada sobre ella.

\section{Sondeo S.G.O.P.-3}

Su emplazamiento preciso corresponde a los terrenos de la piscina municipal de Vallecas, en las proximidades del estadio Rayo Vallecano. La embocadura se sitúa a la cota 642 metros y la profundidad alcanzada con el sondeo fue de 180,20 metros, extrayéndose, como en los sondeos anteriores, testigo continuo. Se realizó entubado hasta los $35 \mathrm{me}-$ tros, utilizándose corona de widia y tubo sencillo de $\varnothing 150$ milímetros hasta los 5,70 metros y tubo doble de $\varnothing 74 \mathrm{mi}$ límetros en el resto.

De forma similar al sondeo del Polideportivo de San Blas, este sondeo presenta una columna litológica constituída por tres unidades litoestratigráficas cuyos rasgos muestran escasas variaciones con los observados en aquel sondeo (fig. 4):

\section{Unidad de arcosas con sepiolita}

Su espesor en este punto es de unos 32 metros (entre 1,70 y 34 metros de profundidad). Salvo dos niveles de muy baja recuperación de testigos constituídos por arenas arcósicas gruesas, la unidad está esencialmente formada por niveles de arcillas más o menos arenosas con bancos finos de carbonatos blanquecinos y algunos niveles sepiolíticos. Son rasgos típicos de todos estos niveles la presencia de bioturbación de raíces y de enrojecimientos relacionados con procesos edáficos de carácter hidromórfico, todo ello característico, junto con las litofacies señaladas, de depósitos propios de zonas distales de abanico.

\section{Unidad de lutitas verdes con arenas micáceas y carbonatos}

Los niveles correspondientes a esta unidad son atravesados entre los 34-74 metros de profundidad en el sondeo. La característica más constante es la presencia de niveles de lutitas verdosas masivas, ocasionalmente muy oscuras, en las que los indicios de laminación paralela o convolucionada están prácticamente borrados por bioturbación intensa de raíces y/o gusanos. En la parte alta de la unidad destacan varios niveles de arenas micáceas, mientras que hacia la base son más frecuentes los carbonatos en forma de nódulos o bien en bancos más continuos.

\section{Unidad de yesos tableados y arcillas}

Salvo los primeros nueve metros, en las arcillas verdosas do la unidad suprayacente comienzan a intercalar algunos nódulos de yeso y nivelitos de yesos fibrosos entre arcillas más grises laminadas, el resto de la sucesión hasta 180,20 metros se caracteriza por una alternancia monótona de banquitos yesíferos, generalmente nodulosos, y arcillas grises con laminación paralela de orden milimétrico. Esta alternancia se mantiene de forma constante variando únicamente las proporciones relativas de espesor yeso/arcilla. Son, en cualquier caso, poco abundantes los bancos yesíferos con espesores superiores a los 20-25 centímetros. En la parte más inferior de esta sucesión evaporítica se han reconocido algunos niveles finos de halita y otros con indicios de sulfatos sódicos.

\section{Discusión}

La información obtenida a partir de las columnas de sondeo anteriormente descritas permite extraer diversas conclusiones do índole litoestratigráfica y sedimentológica que suponen un avance de interés en cuanto al conocimiento de las características geológicas del entorno de Madrid. Conviene señalar, sin embargo, que, dado su carácter puntual, estos datos sirven para esclarecer las pautas litoestratigráficas de las áreas en que están ubicados los sondeos y dejan abiertos interrogantes sobre la distribución precisa de las distintas litofacies en el conjunto del subsuelo de Madrid.

Los resultados extraídos de los tres sondeos estudiados pueden ser resumidos bajo los siguientes aspectos: $a$ ) delimitación en el subsuelo de Madrid de unidades litoestratigráficas rconocidas en superficie, b) caracterización litológica y sedimentológica de los términos que componen dichas unidades, $c$ ) evolución lateral de las unidades y litofacies con verificación y definición de los cambios laterales entre ellas.

Tanto el sondeo SGOP-2 como el SGOP-3 ponen en evidencia la continuidad lateral y superposición en el subsuelo del casco urbano de tres de las unidades litoestratigráficas aflorantes al sur y este de Madrid (Calvo et al., 1983). La columna litológica en el sondeo del Polideportivo de San Blas permite una correlación directa con la parte superior de la secuencia miocena observada en el límite oriental del casco urbano (cortijo de Farnesio, estación de O'Donneil, cerro de la Mesa, alrededores de Vicálvaro). En todo este área afloran de forma más o menos continua depósitos arcósicos con niveles silíceos a techo y capas de sepiolita a la base, que reposan sobre niveles de lutitas verdes, arenas micáceas y bancos discontinuos de carbonatos, términos éstos generalmente mal expuestos en los afloramientos. En la columna del sondeo de San Blas se han reconocido ambas unidades, con una potencia total de 36 metros de arcosas coronadas por silcretas y hasta 8 metros de bancos basales de sepiolita, que pasan gradualmente hacia abajo a una sucesión continua de unos 54 metros de espesor de las facies lutíticas y arenosas finas (micáceas) con carbonatos. Un punto de interés es la localización en profundidad (cota absoluta de 587 metros) del techo de los niveles yesíferos, representados por alternancias monótonas de lutitas grises y yesos nodulares, los cuales se continuan con muy escasa variación (algunas intercalaciones de lutitas verdes bioturbadas o, más raramente, arenas) hasta el final del sondeo.

Por su parte, el sondeo realizado en Vallecas ha permitido establecer el desarrollo que presentan estas mismas unidades litoestratigráficas en el área sur del casco urbano y de las cuales se posee un registro muy discontinuo en afloramiento. Algunas de las pautas de relación entre litofacies en esta zona han sido descritas por Jiménez Salas y Serrano (1973), Geocisa (1982) y Calvo et al. (1983). La unidad arcósica, con 32 metros de potencia obtenida en el sondeo, se sitúa a una cota similar a la de la sucesión aflorante algo más al norte en el Parque de San Diego (Vallecas) (Calvo, 1983), resaltando en la columna del sondeo la gran escasez, en comparación con aquel afloramiento, de niveles arcósicos lavados y su casi total sustitución por secuencias monótonas de arcillas arenosas edafizadas. La unidad de lutitas verdes $y$ arenas presenta una potencia aproximada de unos 40 metros, mostrando en su parte inferior un tránsito aparentemente gradual a arcillas grises oscuras con yesos. E techo de esta unidad evaporítica se situaría a una cota absoluta de unos 568 metros en el punto del sondeo.

El análisis detallado de estas columnas litológicas pone de manifiesto las asociaciones de facies más características en los materiales que componen el subsuelo de Madrid. La unidad superior aparece constituída por secuencias granodecrecientes de arenas moderadamente lavadas y arcillas arenosas afectadas a techo por procesos más o menos intensos de edafización de carácter hidromórfico. Localmente, la presencia de niveles bien desarrollados de silcretas evidencian 
una mayor estabilización del sistema deposicional. Los niveles de sepiolita, generalmente desarrollados a la base de la unidad, representan niveles de policondensación edáfica o bien facies lacustres marginales.

La unidad de lutitas verdes se presenta constituida por tres términos característicos: lutitas verdes masivas (esmectitas como mineral arcilloso esencial) frecuentemente muy bioturbadas, arenas micáceas (biotita predominante) en lechos de espesor medio a fino, y niveles de carbonatos. Desde un punto de vista sedimentológico esta asociación puede ser caracterizada como propia de un ambiente palustre o lacus-
SGOP-1, en términos relativos el más próximo al área fuente del Sistema Central, donde las asociaciones de facies son características, de una forma más persistente, de las zonas distales de abanicos arcósicos, aunque en cualquier caso muestran también una tendencia progradante hacia el techo de la sección.

Esta evolución en la vertical así como en horizontal (S-N) hacia facies más proximales de abanico, queda patentizada con la distribución de litofacies obtenida en diversos sondeos a lo largo del río Manzanares (Aguila, 1962). La ampliación de este modelo de repartición de facies al conjunto del sub.

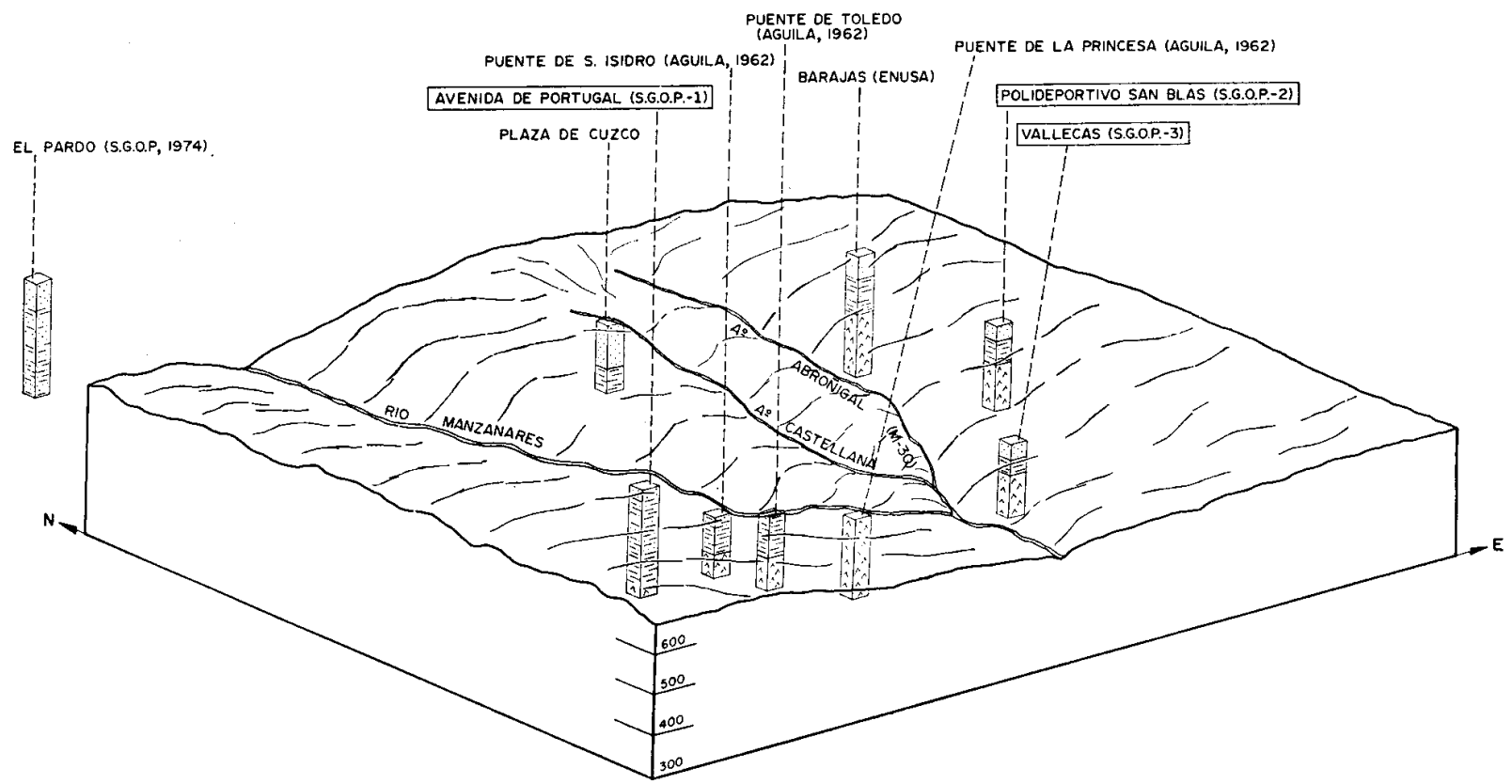

Fig. 5.-Bloque diagrama del área de Madrid con localización de los principales sondeos realizados en ella.

tre somero, con entradas esporádicas de aportes terrígenos más gruesos diferenciados a partir de los abanicos arcósicos. Por último, la unidad de yesos tableados inferior presenta como términos litológicos característicos niveles de yesos nodulares de tamaño variable y lutitas finamente laminadas con lechos finos algo micáceos y restos de vegetales flotados. Son de señalar las evidencias petrográficas que conducen a pensar en la anhidrita como mineral precursor de gran parte de los yesos actualmente observables (García del Cura, comunicación personal, 1983). La halita y otros sulfatos sódicos han sido únicamente reconocidos en niveles muy finos en el sondeo más meridional (SGOP-3). Señalaremos, asimismo, la fuerte diferencia observada en cuanto a mineralogía de arcillas entre esta unidad y las lutitas verdes suprayacentes. La asociación de facies observada en esta unidad evaporítica se interpreta como propia de un ambiente lacustre evaporítico con amplio desarrollo de llanuras fangosas.

La exposición de la naturaleza litológica de las diferentes unidades corresponde esencialmente a las columnas obtenidas en los sondeos de San Blas y Vallecas, en los que dichas unidades aparecen netamente diferenciadas, formando en conjunto una megasecuencia de carácter progradante. Esta situación aparece algo más difusa en la columna del sondeo suelo de Madrid ha sido propuesta por diversos autores (García Yaglie, 1973; López Vera, 1975; Llamas y López Vera, 1975; Martínez Alfaro, 1978; Hoyos et al., 1984) y ha sido, asimismo, evidenciado, a pesar de la escasa profundidad de los sondeos, en las investigaciones previas a la construcción de nuevas líneas del Metro (Escario, 1969; Agroman, 1973; Laboratorio del Transporte, 1978; Geocisa, 1982; etcétera). Los resultados obtenidos en los sondeos que han sido descritos en el presente trabajo confirman y complementan estos datos y suponen una importante aportación al cuadro general de la distribución de litofacies en el subsuelo de Madrid (fig. 5).

\section{Conclusiones}

La realización de tres nuevos sondeos rofundos de investigación geológica propiciados por el Servicio Geológico de Obras Públicas en el subsuelo del casco urbano de Madrid ha permitido la localización y caracterización en cuanto a espesores y litofacies de las 
principales unidades litoestratigráficas que constituyen dicho subsuelo.

El análisis sedimentológico de las facies observadas conduce al establecimiento de un modelo evolutivo en ambiente continental de carácter progradante desde depósitos de abanicos aluviales de naturaleza arcósica (facies medias y distales) a depósitos palustres y lacustres evaporíticos.

Las relaciones entre la sucesión de materiales reconocidos en cada uno de los sondeos y entre éstos y los datos existentes sobre el subsuelo de Madrid, confirma la existencia con carácter general de cambios laterales de facies dentro de cada unidad según el modelo anteriormente señalado. Estos cambios alcanzarían su máxima expresión a profundidades comprendidas entre las cotas 400 y 600 metros en la transversal entre Vallecas y la Casa de Campo.

Se subraya, por último, la necesidad de nuevos datos como los aquí presentados de cara a una definición más detallada del sistema deposicional que caracteriza el Mioceno en el área de Madrid.

\section{Bibliografía}

AGROMÁn

1973. Datos de geología aplicada del subsuelo de Madrid. Informe inédito.

Aguila, A.

1962. Exploraciones recientes en el subsuelo yesífero de Madrid capital. I Col. Internac. sobre Obras Públicas en Terrenos Yesíferos, S.G.O.P., Madrid, $5,1-5$.

Alberdi, M. T.; Hoyos, M.; Junco, F.; López-Martínez, N.; Morales, J.; Sesé, C. y Soria, D.

1983. Biostratigraphie et évolution sédimentaire du Néogene continental de l'aire de Madrid. InterimColl. RCMNS. Paleoclimatic Evol., Montpelier, 15-18.

Calvo, J. P.

1983. Punto de Interés Geológico del Parque de San Diego, en: "Recursos geológico-culturales del Término Municipal de Madrid", Ayuntamiento de Madrid.

Calvo, J. P. et al.

1984. Resumen de resultados del "Estudio geológico a escala 1/25.000 del Término Municipal de Madrid". Simposio sobre Getoctonología del Subsuelo de Madrid (en prensa).

Calvo, J. P.; Ordóñez, S.; Hoyos, M. y García del Cura, M. A.

1984. Caracterización sedimentológica de la Unidad Intermedia del Mioceno al sur de Madrid. Rev. Mat. Proc. Geol., 2 (en prensa).

ESCARIO, V.

1969. Los suelos de Madrid. Laboratorio del Transporte

y Mecánica del suelo. Publ. núm. 25
Escario, V. Y Salinas, J. L

1984. Cambios laterales de facies en el subsuelo de Madrid. Simposio sobre Geotecnología del Subsuelo de Madrid (en prensa).

García Yagüe, A.

1973. La geología de Madrid. Rev. Obras Públicas, 10431055

GeocisA

1982. Informe geotécnico complementario. Tramo Portazgo-Santa Eugenia. Informe inédito.

Hoyos, M.; Junco, F.; Plaza, J.; RamíRez, A. y Ruiz, J.

1984. El Mioceno de Madrid. Comunidad Autónoma de Madrid (en prensa).

Jiménez Salas, J. A. y Serrano, G.

1975. Reconocimiento estratigráfico de detalle de la Unidad Alimentaria de Mercamadrid. Informe inédito.

Junco, F, y Calvo, J. P.

1984. Cuenca de Madrid, en "Libro Homenaje a J. M. Ríos, IGME (en prensa).

Llamas, R, y López Vera, F.

1975. Estudio sobre los recursos hidráulicos subterráneos del área metropolitana de Madrid y su zona de influencia: avance de las características hidrogeológicas del Terciario detrítico de la Cuenca del Jarama. Agua, 88, 36-55.

Martínez Alfaro, P. E.

1978. Contribución al conocimiento de la geología del casco urbano de Madrid. Estudios geol., 34, 241-249.

Megías, A. G.; Ordóñez, S. y Calvo, J. P.

1980. Rupturas sedimentarias en series continentales: aplicación a la Cuenca de Madrid. Comunicaciones IX Congreso Nacional de Sedimentología, Salamanca (en prensa).

Megías, A. G.; Legüey, S. y Ordóñez, S.

1982. Interpretación tectosedimentaria de la génesis de fibrosos de la arcilla en series detríticas continentales (cuencas de Madrid y del Duero). Quinto Congreso Latinoamericano de Geología, Buenos Aires, 2, 427-439.

Megías, A. G.; Ordóñez, S: y Calvo, J. P.

1983. Nuevas aportaciones a la geología de la cuenca de Madrid. Rev. Mat. Proc. Geol., 1, 163-192.

RIBA, 0.

1957. Terrasses du Manzanares et du Jarama aux environs de Madrid. INQUA, V Congr. Intern., Livret-guide, Exc 5-55.

RoYo Gómez, J.

1929. Memoria y hoja geológica 1/50.000 de Madrid. Mapa Geal. Nac. $1 .^{\mathrm{a}}$ serie, IGME, Madrid.

Torres Pérez-Hidalgo, T.; Junco, F.; Zapata, J. L. y Pla$\mathrm{ZA}, \mathbf{J}$.

1984. Similitud de los procesos sedimentarios del Neógeno en la cuenca del Tajo y en la Depresión Intermedia. I Congreso Español de Geología, 1, 285-300. 